\title{
GROWTH PARAMETERS AND POPULATION STRUCTURE OF ARISTEUS ANTENNATUS (DECAPODA, PENAEIDAE) IN THE SOUTH TYRRHENIAN SEA (SOUTHERN COAST OF ITALY)
}

\author{
BY \\ M. ARCULEO ${ }^{1,4}$ ), S. VITALE ${ }^{2}$ ), L. CANNIZARO ${ }^{3}$ ) and S. LO BRUTTO ${ }^{1}$ ) \\ 1) Dipartimento di Biologia Ambientale e Biodiversità, Sezione di Biologia Animale ed \\ Antropologia Biologica, Via Archirafi, 18, I-90123 Palermo, Italy \\ 2,3 ) Consiglio Nazionale delle Ricerche, Istituto per l'Ambiente Marino Costiero, sections of: \\ 2) Mazara del Vallo, via Luigi Vaccara, 61, I-91026 Mazara del Vallo, Italy \\ 3 ) Capo Granitola, via del Faro, 3, I-91021 Campobello di Mazara, Italy
}

\begin{abstract}
The blue and red shrimp Aristeus antennatus (Risso, 1816) is one of the most important fishery resources in the Mediterranean Sea. Monthly samplings of blue and red shrimp from June 2006 to May 2007 were landed by the trawl fleet in two northwest Sicilian fishing harbours (San Vito Lo Capo and Terrasini). The carapace length (CL) frequency distribution of females ranged between 15.00 and $59.00 \mathrm{~mm}$, whereas male CLs ranged between 17.00 and $34.00 \mathrm{~mm}$. The estimated parameters of the Von Bertalanffy growth function (VBGF) for San Vito lo Capo females and males were: $\mathrm{CL} \infty=65 \mathrm{~mm}, \mathrm{~K}=0.58 \mathrm{y}^{-1}$ and $\mathrm{CL} \infty=41 \mathrm{~mm}, \mathrm{~K}=0.71 \mathrm{y}^{-1}$, respectively; while for Terrasini females and males these were: $\mathrm{CL} \infty=69 \mathrm{~mm}, \mathrm{~K}=0.65 \mathrm{y}^{-1}$ and CL $\infty=37 \mathrm{~mm}$, $\mathrm{K}=0.8 \mathrm{y}^{-1}$, respectively. In this study, we update the information on stock structure and growth parameters of the blue and red shrimp in two northwest Sicilian fishing grounds and compare these results with other data recorded in the Mediterranean Basin.
\end{abstract}

\section{RIASSUNTO}

Il gambero viola Aristeus antennatus (Risso, 1816) è una delle risorse da pesca più importanti nel Mar Mediterraneo. L'indagine è stata effettuata in due marinerie della sicilia nord-occidentale (San Vito Lo Capo e Terrasini) dove mensilmente e in un periodo compreso tra giugno 2006 e maggio 2007, venivano acquistati allo sbarco campioni di gambero viola. La distribuzione di frequenza di lunghezza carapace (LC) delle femmine era compresa tra 15,00 e 59,00 mm, mentre nei maschi tra 17,00 e 34,00 mm. I parametri di crescita stimati con la funzione di Von Bertalanffy (VBGF) per le femmine e i maschi di San Vito Lo Capo sono risultati rispettivamente di: CL $\infty=65 \mathrm{~mm}, \mathrm{~K}=0,58$ $\mathrm{y}^{-1}$ e $\mathrm{CL} \infty=41 \mathrm{~mm}, \mathrm{~K}=0,71 \mathrm{y}^{-1}$, mentre per le femmine ed i maschi di Terrasini sono stati: $\mathrm{CL} \infty=69 \mathrm{~mm}, \mathrm{~K}=0,65 \mathrm{y}^{-1}$ e $\mathrm{CL} \infty=37 \mathrm{~mm}, \mathrm{~K}=0,8 \mathrm{y}^{-1}$. In questo studio vengono

4) e-mail: marculeo@unipa.it

(C) Koninklijke Brill NV, Leiden, 2011 
aggiornate le informazioni sulla struttura dello stock e i parametri di crescita di questa specie in due aree precedentemente indagate e vengono, inoltre confrontati questi risultati con altri riportati in altre aree del Mediterraneo.

\section{INTRODUCTION}

The blue and red shrimp Aristeus antennatus (Risso, 1816) is distributed throughout the Atlantic Ocean and the Mediterranean Sea, with the exception of the Adriatic Sea (Holthuis, 1980; Ribeiro-Cascalho \& Arrobas, 1982), and it represents one of the most important fishery resources for many Mediterranean countries. Along the northwestern coast of Sicily this resource has been exploited for a long time by different fleets, and its catch is facilitated by the gently sloping seabed beyond the continental shelf.

The blue and red shrimp trawling takes place on the mud bottoms of the lower continental shelf and the upper continental slope down to $\sim 800 \mathrm{~m}$ deep (Holthuis, 1980). Traditionally, along the northwestern coast of Sicily, fishing harbours like San Vito Lo Capo and Terrasini focused their interest quite exclusively on the crustacean trawl fishery in view of the economic advantages, rather than targeting fishes like, e.g., hake, Merluccius merluccius (Linnaeus, 1758) or red mullet Mullus barbatus (Linnaeus, 1758).

Considering its high economic value, the blue and red shrimp has been the object of numerous research studies addressing their reproductive cycle (Arculeo et al., 1995 and references therein), catch estimations, ecology, population structure (Demestre \& Lleonart, 1993; Fiorentino et al., 1998; Cau et al., 2002; Sardà et al., 2004; D'Onghia et al., 2005; Arculeo, 2008; Guijarro et al., 2008), and more recently genetic variation (Roldan et al., 2008; Maggio et al., 2009). Investigations on both population and genetic structure can contribute to the knowledge of, for example, whether or not the species is overexploited and whether or not it is represented by different unit stocks; knowledge that may provide useful information in recovery programmes or other management activities.

The main goal of the present study was to update the information on stock structure and growth parameters computed during a monitoring programme in two north-western Sicilian fishing harbours, and to compare these results with other data recorded in the Mediterranean Basin.

\section{MATERIAL AND METHODS}

A preliminary survey was undertaken in each of the sample harbours of San Vito Lo Capo and Terrasini (fig. 1). Monthly samplings from June 2006 to May 2007 were landed by the trawl fleet in both these harbours. 


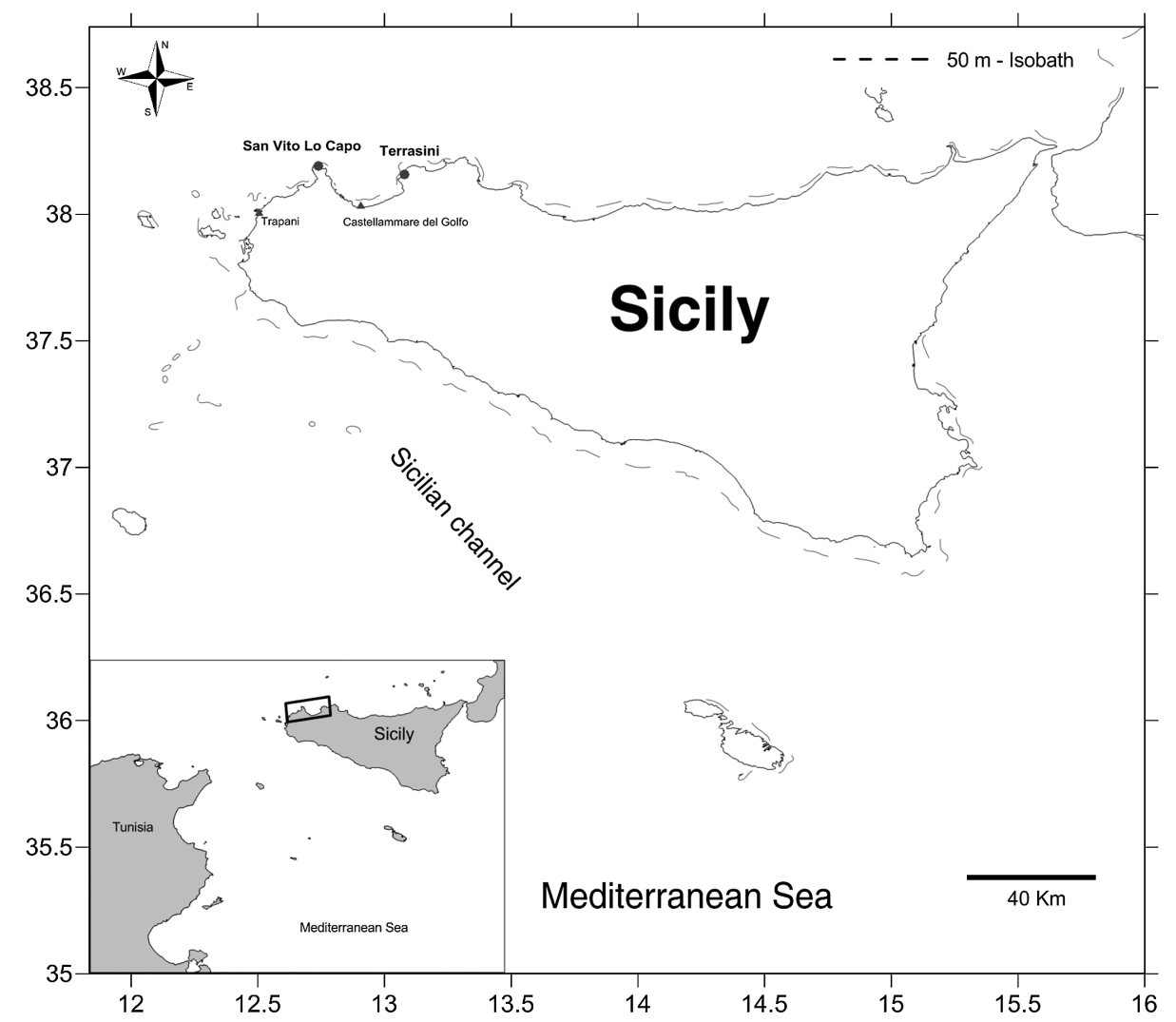

Fig. 1. Map of the study area showing the San Vito Lo Capo and Terrasini sample harbours.

Individual Aristeus antennatus were sexed and the carapace length (CL) and weight of each specimen was measured; the CL was measured to the nearest $0.01 \mathrm{~mm}$, from the posterior margin of the orbit to the posterior edge of the carapace, using electronic callipers, and weight was measured to the nearest $0.01 \mathrm{~g}$ with a technical balance.

The VBGF (Von Bertalanffy Growth Function) was used to estimate growth parameters. The estimation of growth parameters was conducted using the electronic length frequency analysis I (ELEFAN I) routine incorporated in the FAO-ICLARM Stock Assessment Tools II (FISAT II) software (Gayanilo et al., 2005). Algorithms of the routinely required inputs of seeded CL $\infty$ and $\mathrm{K}$ within an at least biologically acceptable range. The initial value of $C L \infty$ was computed according to the relationship obtained by Taylor (1962). In order to compare growth performance, the most common empirical equation by Pauly \& Munro (1984) was used.

Length-frequency distributions for both sex and area were used to estimate the modal class values using the Bhattacharya method (FISAT II). Each modal separation, with a separation index (S.I.) greater than 2, was assumed to be a single 
cohort. Monthly size frequency distributions at both sites were compared by sex. The statistical significance of the results of this comparison was tested by the Mann-Whitney U-test and the Kolmogorov-Smirnov test.

\section{RESULTS}

The San Vito Lo Capo fleet operates two crustacean trawl fisheries near the Trapani area, while six crustacean trawl fisheries of the Terrasini harbour operate in the Gulf of Castellammare. Both fleets operate at the same depth, usually between 400 and $700 \mathrm{~m}$, and use the same mesh size (40 mm diamond) at the cod ends of the nets. A total of 14624 blue and red shrimps, Aristeus antennatus (12920 female, 1704 male) were analysed from San Vito Lo Capo and 11112 (9816 female, 896 male) from Terrasini. In the harbour of San Vito Lo Capo the CL frequency distribution of females ranged between 15.00 and $59.00 \mathrm{~mm}$ (female mean $\mathrm{CL}=36.08 \mathrm{~mm}$; sd $=6.69$ ), whereas in the Terrasini harbour it ranged between 18.00 and $59.00 \mathrm{~mm}$ (female mean $\mathrm{CL}=38.75 \mathrm{~mm}$; $\mathrm{sd}=7.72$ ). Male $\mathrm{CL}$ ranged between 17.00 and $34.00 \mathrm{~mm}$ (male mean $\mathrm{CL}=24.88 \mathrm{~mm}$; $\mathrm{sd}=2.85$ ) in San Vito lo Capo, and between 18.00 and $32.00 \mathrm{~mm}$ (male mean $\mathrm{CL}=24.66 \mathrm{~mm}$; $\mathrm{sd}=3.17)$ in Terrasini. The highest frequency of the female CL was between 32.00 and $42.00 \mathrm{~mm}$ in San Vito Lo Capo and between 38.00 and $48.00 \mathrm{~mm}$ in Terrasini, whereas the highest CL frequency of the males was recorded between 22.00 and $28.00 \mathrm{~mm}$ in San Vito Lo Capo and between 24.00 and $28.00 \mathrm{~mm}$ in Terrasini (fig. 2; table I). The statistical comparison of the overall and monthly size frequency distributions at both sites and by sex, highlighted a significant difference for females $(p<0.05)$ while no significant difference $(p>0.05)$ was recorded for males.

The estimated parameters of the VBGFs for San Vito lo Capo females and males were: $\mathrm{CL} \infty=65 \mathrm{~mm}, \mathrm{~K}=0.58 \mathrm{y}^{-1}$ and: $\mathrm{CL} \infty=41 \mathrm{~mm}, \mathrm{~K}=0.71 \mathrm{y}^{-1}$, respectively; while for Terrasini females and males they were: $C L \infty=69 \mathrm{~mm}$, $\mathrm{K}=0.65 \mathrm{y}^{-1}$ and: $\mathrm{CL} \infty=37 \mathrm{~mm}, \mathrm{~K}=0.8 \mathrm{y}^{-1}$, respectively. The estimated growth parameters of the blue and red shrimp within the Mediterranean Basin obtained from other studies are compared in table II.

The CL frequency distribution pooled over 12 months was used (Bhattacharya's method) to identify the modes for both sexes. In San Vito Lo Capo and Terrasini the females showed four dominant age groups, whereas three modes were identified for the males (table III).

\section{DISCUSSION}

The observed CL values of Aristeus antennatus can be reasonably compared with the CL values reported for the same area in previous investigations (Arculeo et 


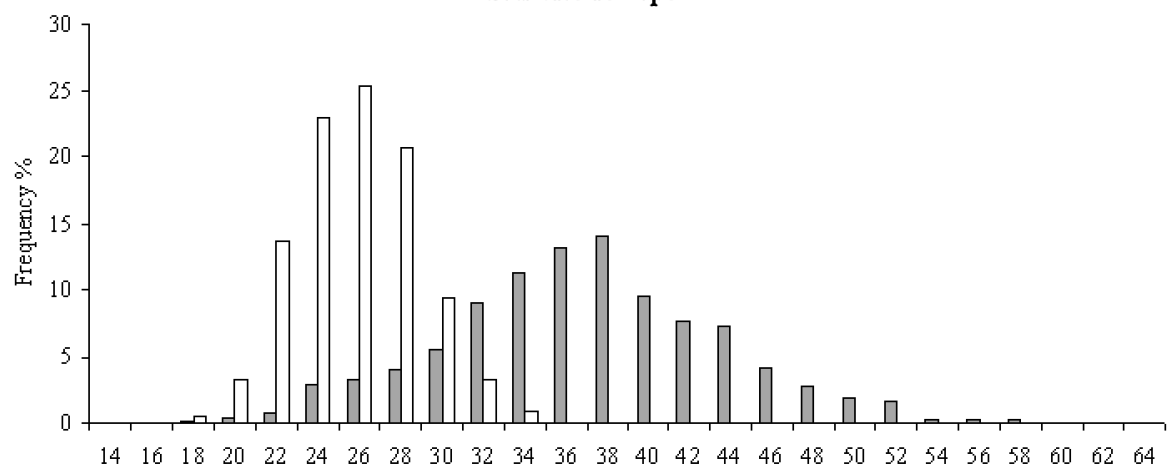

$\square$ Female $\square$ Male

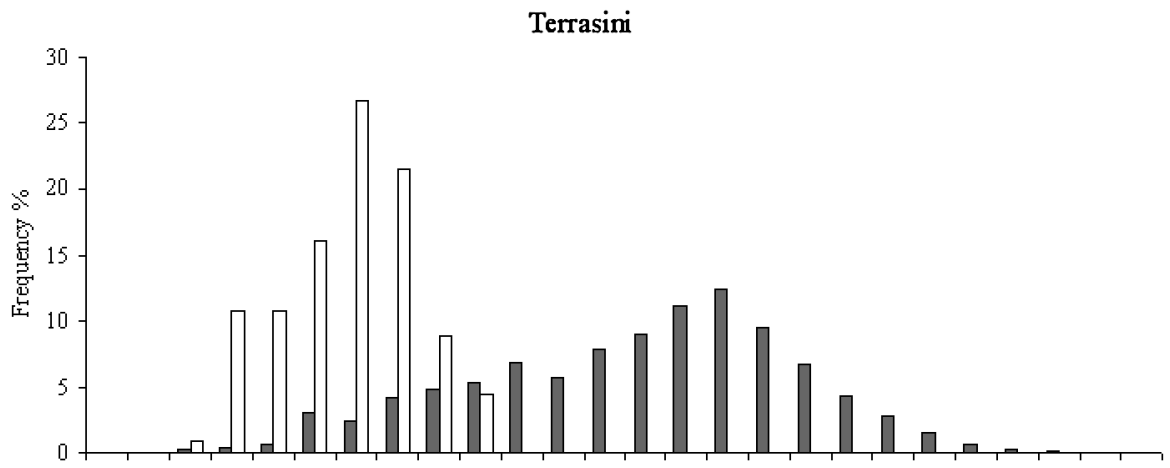

$\begin{array}{llllllllllllllllllllllllll}14 & 16 & 18 & 20 & 22 & 24 & 26 & 28 & 30 & 32 & 34 & 36 & 38 & 40 & 42 & 44 & 46 & 48 & 50 & 52 & 54 & 56 & 58 & 60 & 62 & 64\end{array}$ $\square$ Female $\square$ Male

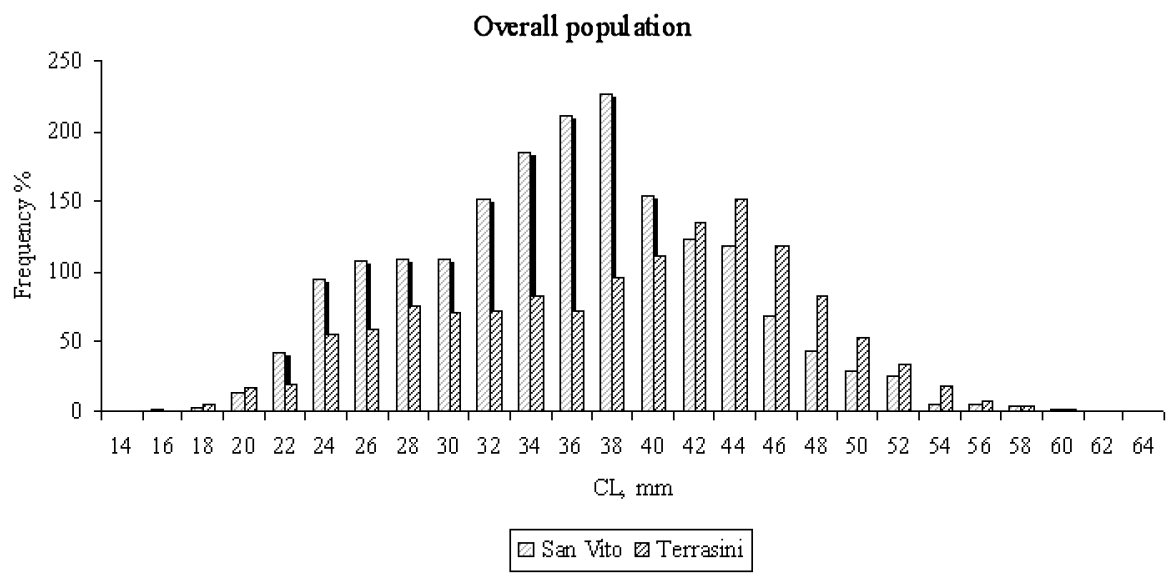

Fig. 2. Length-frequency distribution of the males and females of Aristeus antennatus (Risso, 1816) in the southern Tyrrhenian Sea. 
TABLE I

Number of specimens, mean, modes and range values of the CL for sexes and sample harbours of Aristeus antennatus (Risso, 1816)

\begin{tabular}{lccccc}
\hline & $\mathrm{N}^{\circ}$ specimens & \multicolumn{1}{c}{ Mean CL mm } & CV & CL mode mm & CL range mm \\
\hline Females & 12920 & 36.08 & $19 \%$ & $32-42$ & $15-59$ \\
Males & 1704 & 24.88 & $11 \%$ & $22-28$ & $17-34$ \\
& & \multicolumn{5}{c}{ San Vito Lo Capo } \\
Females & 9816 & 38.75 & $20 \%$ & $38-48$ & $18-59$ \\
Males & 896 & 24.66 & $13 \%$ & $24-28$ & $18-32$ \\
\hline
\end{tabular}

al., 1992, 1994; Arculeo, 2008) and with other exploited areas in the Mediterranean Sea (Yahiaoui et al., 1986; Matarrese et al., 1992; Spedicato et al., 1995; Ragonese \& Bianchini, 1996; Cau et al., 2002). This similarity between the reported minimum and maximum values of the CL in the exploited fishing grounds analysed suggests, that over the last few decades the habits of the fishermen, the characteristics of the gear (mesh of cod end), and the depths of the blue and red shrimp catches in the Southern Tyrrhenian Sea, Strait of Sicily, and in some areas of the Ionian Sea, have probably not undergone substantial modifications. The least differences were recorded with the data reported by Papaconstantinou \& Kapiris (2001) from the non-exploited stock in Greek Ionian waters and in the western part of the Mediterranean (Sardà et al., 2004).

The length frequency analysis showed four possible age classes in San Vito Lo Capo and Terrasini, and although the values of these modes were slightly different, they were reasonably comparable. The population structure of San Vito Lo Capo was found to be mainly characterized by specimens of the second age group (76\%) for both sexes, whereas in Terrasini females were most abundant in the third age group (58\%) and males in the second age group (87\%). The data for the males were more unpredictable and conclusions harder to reach.

Considering that both fleets exclusively exploited each blue and red shrimp fishing ground, the above highlighted differences cannot be associated with the different fishing efforts enforced by the six vessels of Terrasini or the two vessels of San Vito Lo Capo. In addition, observing the CL distribution (fig. 2) and considering the fact that both fisheries operate at the same depths and with similar gear, it seems reasonable to hypothesize that environmental factors could have an influence on the spatio-temporal distribution, and therefore also on the recruitment of this species.

Along the fishing grounds off the Balearic Islands, Guijarro et al. (2008) showed moderate spatial and temporal differences between the two different sample sites analysed, that were related to the different environmental conditions. In fact, at 
BIOLOGY OF ARISTEUS ANTENNATUS IN S. TYRRHENIAN SEA

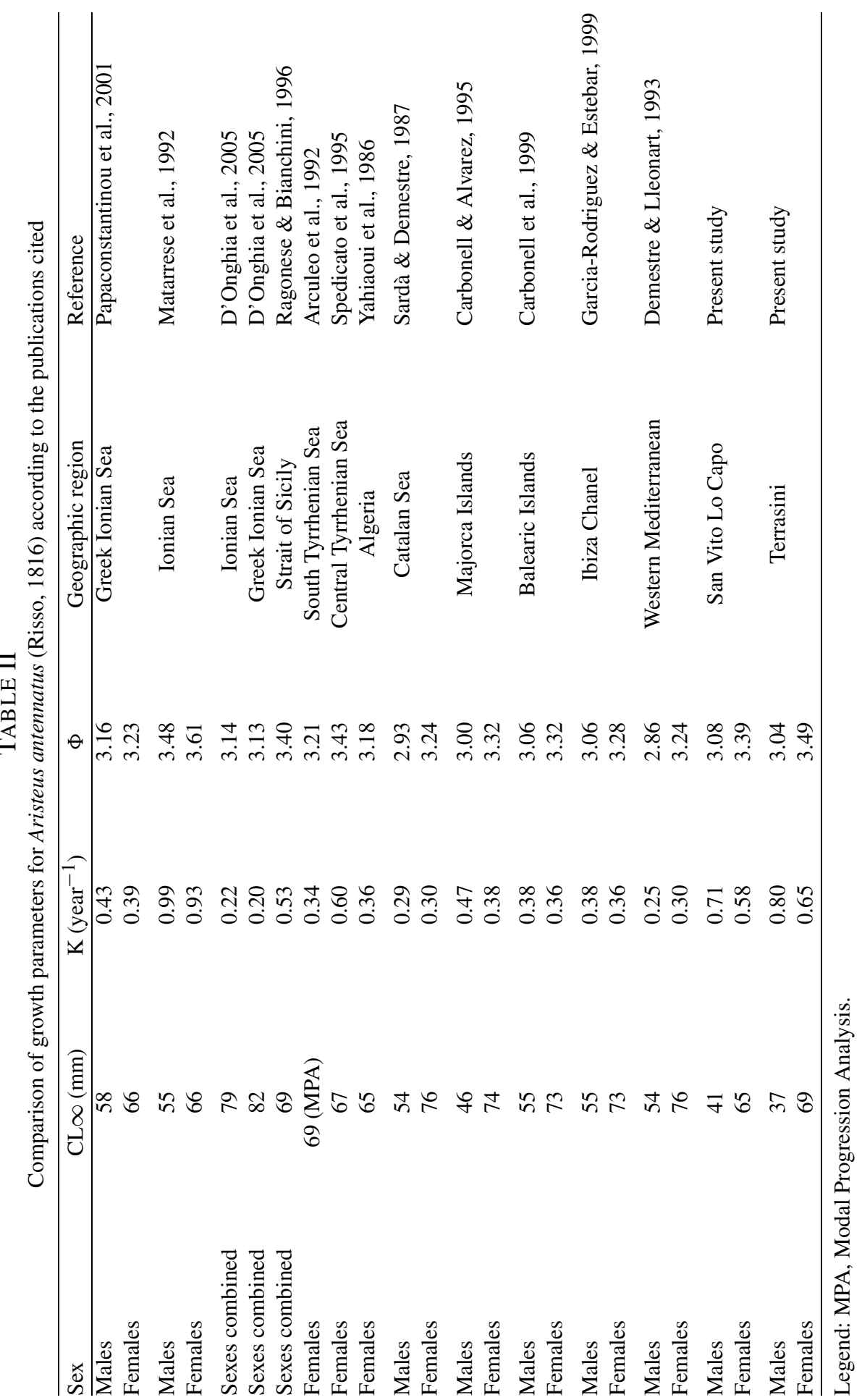


TABLE III

Stock structure of Aristeus antennatus (Risso, 1816) for both sexes and sample harbours

\begin{tabular}{|c|c|c|c|c|}
\hline Cohorts & 1 & 2 & 3 & 4 \\
\hline & \multicolumn{4}{|c|}{ San Vito Lo Capo } \\
\hline Females & 25.25 & 36.19 & 46.44 & 57.00 \\
\hline S.I. & n.a. & 2.33 & 2.11 & 2.22 \\
\hline Males & 24.21 & 27.80 & 31.98 & - \\
\hline \multirow[t]{2}{*}{ S.I. } & n.a. & 2.25 & 2.57 & - \\
\hline & \multicolumn{4}{|c|}{ Terrasini } \\
\hline Females & 23.91 & 32.29 & 42.86 & 51.85 \\
\hline S.I. & n.a. & 2.22 & 2.18 & 2.10 \\
\hline Males & 19.92 & 26.39 & 30.50 & - \\
\hline S.I. & n.a. & 3.69 & 3.56 & - \\
\hline
\end{tabular}

Legend: S.I., separation index.

one site they found a more demographically homogeneous population, whereas the other site showed important variations, such as a high abundance of juveniles being recruited to the fishing grounds. According to Guijarro et al. (2008) and references therein, the importance of water mass movements in size distribution and abundance of blue and red shrimp is indisputable.

The same observation was also reported by Maggio et al. (2009), who analysed the genetic variation in this species in different parts of the Mediterranean Sea; in particular, those authors did not find any significant difference between the samples and hypothesized, as also reported by Cartes et al. (2008), that such genetic homogeneity is strictly correlated with: (i) the biological characteristics of this species; (ii) the horizontal and vertical fluctuations of the water masses; and (iii) the spatio-temporal variations in the chemical/physical factors and the trophic resources. Of course, it is important that further ad hoc oceanographic investigations are undertaken to verify whether or not these differences between our sample sites are linked to environmental conditions.

The number of estimated age classes in the Tyrrhenian Sea (Arculeo et al., 1994; Arculeo, 2008; present study) is quite similar to the estimates reported by Ragonese \& Bianchini (1996) from the Strait of Sicily, whereas it is lower than the estimates obtained at both western and eastern sides of the Ionian Sea by Papaconstantinou \& Kapiris (2001) in non-exploited stocks, and by D'Onghia et al. (2005), respectively.

The comparison of the estimated growth parameters for females (table I) by the VBGF seemed to show more affinity to the central-southern Tyrrhenian Sea and the Strait of Sicily (Yahiaoui et al., 1986; Arculeo et al., 1992; Spedicato et al., 1995; Ragonese \& Bianchini, 1996) than the higher growth parameter estimates 
reported in the western Mediterranean Sea (Sardà \& Demestre, 1987; Demestre \& Lleonart, 1993; Carbonell \& Alvarez, 1995; Carbonell et at., 1999; GarciaRodriguez \& Esteban, 1999) and in some areas of the Ionian Sea (Matarrese et al., 1992; Papaconstantinou \& Kapiris, 2001; D'Onghia et al., 2005). The growth performance index suggests that in our sample, as reported in table I, growth is faster in females than in males. Such differences in growth parameters could be attributed to the diverse degree of exploitation of the blue and red shrimp over time, or to the different fishing habits (net size, depth of catch, etc.) among the fishermen exploiting the various Mediterranean fishing grounds. Moreover, as hypothesized above, these differences could be also attributed to the particular oceanographic conditions (Guijarro et al., 2008) that are able to influence the abiotic (climate and hydrodynamics) and biotic (trophic resources and predators) variables. In support of this consideration, we can add that this species shows a marked dissimilarity in reproductive behaviour between northern and more southern populations, and that these differences may be referred to as an expression of a biogeographical gradient, or a different adaptation to the conditions of the bathyal system (Margalef, 1985; Mura \& Cau, 1989; Arculeo et al., 1995). An alternative hypothesis could sustain that such differences are strictly associated with the peculiar aspects of the fishing activities in both the central-southern Tyrrhenian Sea and the Strait of Sicily, being fishing grounds that have been traditionally exploited for decades already.

Generally, as reported worldwide, the action of the commercial trawl fishery incessantly removes the largest specimens, thereby reducing the overall abundance of the stock and changing its age-length structure; oddly, although this investigation could not provide information about the shrimp's abundance, the age-length structure of the blue and red shrimp in the investigated areas did not seem to be influenced by the action of the trawlers, although further studies are necessary for regular updates of abundance.

\section{ACKNOWLEDGEMENTS}

This research was supported by POR-Sicilia 2000/06 project $n .62$ and by "Fondi di Ateneo (ex 60\%)". We are grateful to Drs M. Vaccaro, E. Favaloro, A. Mistretta, and A. Vivona for collecting samples and laboratory analysis. We are grateful also to Consorzio di Ripopolamento Ittico del Golfo di Castellammare and the Municipality of San Vito Lo Capo.

\section{REFERENCES}

ArCuleo, M., 2008. Analisi dei dati di sbarco del gambero viola Aristeus antennatus (Crustacea, Aristeidae) in due marinerie della Sicilia nord occidentale. Naturalista Siciliano, 32 (4): 221 240. 
Arculeo, M., R. Baino, A. Abella \& S. Riggio, 1992. Accrescimento e riproduzione di Aristeus antennatus (Crustacea, Decapoda) nel Golfo di Castellammare (Sicilia N/W). Oebalia, 17: $117-118$.

$-\ldots,-\ldots,-\ldots \&-\ldots, 1994$. Distribution and growth of Aristeus antennatus in Southern Tyrrhenian Sea. In: M. L. BiAnchini \& S. RAgOnESE (eds.), Procedings of the International workshop "Life cycles and fisheries of the deep-water red shrimps Aristaeomorpha foliacea and Aristeus antennatus". N.T.R. - I.T.P.P.-C.N.R., Special Publications, 3: 43.

Arculeo, M., G. Payen, A. Cuttitta, G. Galioto \& S. Riggio, 1995. A survey of the ovarian maturation in a population of Aristeus antennatus (Crustacea, Decapoda). Animal Biology, 4: $13-18$

Carbonell, A. \& F. Alvarez, 1995. Fishery and biology of Aristeus antennatus, Risso, 1816 on Majorca Island waters. Rapp. Comm. int. Mer Méditerranée, 34: 22.

Carbonell, A., M. Carbonell, M. Demestre, A. Cau \& S. Monserrat, 1999. The red shrimp Aristeus antennatus (Risso, 1816) fishery and biology in the Balearic Islands, western Mediterranean. Fisheries Research, 44: 1-13.

Cartes, J. E., T. Madurell, E. Fanelli \& U. Lopez-Jurado, 2008. Dynamics of suprabenthos-zooplankton communities around the Balearic Islands (western Mediterranean): influence of environmental variables and effects on the biological cycle of Aristeus antennatus. Journal of Marine Systems, 71 (3): 316-335.

Cau, A., A. Carbonell, M. C. Follesa, A. Mannini, G. Norrito, L. Orsi-Relini, C. Y. Politou, S. RAGONESE \& P. Rinelli, 2002. MEDITS-based information on the deepwater red shrimps Aristaeomorpha foliacea and Aristeus antennatus (Crustacea: Decapoda: Aristeidae). Scientia Marina, 66 (2): 103-124.

Demestre, M. \& G. Lleonart, 1993. The population dynamics of Aristeus antennatus (Decapoda: Dendrobranchiata) in the north western Mediterranean. Scientia Marina, 57: 183-189.

D’Onghia, G., F. Capezzuto, C. Mytilineou, P. Maiorano, K. Kapiris, R. Carlucci, L. SION \& A. TURSI, 2005. Comparison of the population structure and dynamics of Aristeus antennatus (Risso, 1816) between exploited and unexploited areas in the Mediterranean Sea. Fisheries Research, 76: 22-38.

Fiorentino, F., L. ORsi Relini, A. ZAMBONI \& G. RELINI, 1998. Remarks about the optimal harvest strategy for red shrimps (Aristeus antennatus Risso, 1816) on the basis of the Ligurian experience. CIHEAM — Options Méditerranéennes, 35: 323-333.

GARCIA-RodrigueZ, M. \& A. EstebAN, 1999. On the biology and fishery of Aristeus antennatus (Risso, 1816) (Decapoda, Dendrobranchiata) in the Ibiza Channel (Balearic Islands, Spain). Scientia Marina, 63: 27-37.

Gayanilo, F. C., JR., P. SPARre \& D. PAUly, 2005. The FAO-ICLARM stock assessment tools II (FiSAT II) reference manual: 1-168. (F.A.O. Computerized Information Series, Fisheries, 8 , Revised version). (F.A.O., Rome).

Guijarro, B., E. Massuti, J. Moranta \& P. Diaz, 2008. Population dynamics of the red shrimp Aristeus antennatus in the Balearic Islands (western Mediterranean): short spatio-ternporal differences and influence of environmental factors. Journal of Marine Systems, 71: 385-402.

Holthuis, L. B., 1980. Shrimps and prawns of the world. An annotated catalogue of species of interest for fisheries. FAO species catalogue, 1. FAO Fish. Synop., 125: 1-261. (FAO, Rome).

Maggio, T., S. Lo Brutto, R. Cannas, A. M. Deiana \& M. Arculeo, 2009. Environmental features of deep-sea habitats linked to genetic population structure of a crustacean species in the Mediterranean Sea. Marine Ecology — An Evolutionary Perspective, 30: 354-365.

MARGALEF, R., 1985. Key environments: western Mediterranean: 1-363. (Pergamon Press, Oxford).

Matarrese, A., G. D'Onghia \& A. Tursi, 1992. Struttura e dinamica dello stock di Aristeus antennatus Risso, 1816 (Crustacea, Decapoda) nel mar Jonio. Oebalia, 17 (2): 61-66.

Mura, M. \& A. CAU, 1989. Sul dimorfismo sessuale e sex-ratio in Aristeus antennatus (Risso, 1816). Oebalia, 15: 811-814. 
Papaconstantinou, C. \& K. Kapiris, 2001. Distribution and population structure of the red shrimp (Aristeus antennatus) on an unexploited fishing ground in the Greek Ionian Sea. Aquatic Living Resources, 14: 303-312.

PAULY, D. \& J. L. MUNRO, 1984. Once more on the comparison of growth in fish and invertebrates. ICLARM Fishbyte, 2: 21.

RAGONESE, S. \& M. L. BIANCHINI, 1996. Growth, mortality and yield-per-recruit of the deep-water shrimp Aristeus antennatus (Crustacea-Aristeidae) of the Strait of Sicily (Mediterranean Sea). Fisheries Research, 26: 125-137.

Ribeiro-Cascalho, A. \& I. Arrobas, 1982. Aristeus antennatus Risso, 1816: some considerations about its biology and fishery in Portuguese water. ICES Journal of Marine Science, $\mathbf{6}$ : 123-133.

Roldan, M. I., S. Heras, R. Patellani \& F. Maltagliati, 2008. Analysis of genetic structure of the red shrimp Aristeus antennatus from the western Mediterranean employing two mitochondrial regions. Genetica, 136: 1-4.

SARDÀ, F. \& M. Demestre, 1987. Estudio biologico de la gamba Aristeus antennatus (Risso, 1816) en el mar Catalan (N.E. de Espana). Investigación Pesquera, Barcelona, 51 (1): 213-232.

Sardà, F., G. D'Onghia, C. Y. Politou, J. B. Company, P. Maiorano \& K. Kapiris, 2004. Deep-sea distribution, biological and ecological aspects of Aristeus antennatus (Risso, 1816) in the western and central Mediterranean Sea. Scientia Marina, 68 (3): 117-127.

Spedicato, M. T., S. Greco, G. Lembo, F. Perdichizzi \& P. Carbonara, 1995. Prime valutazione sulla struttura dello stock di Aristeus antennatus (Risso, 1816) nel Tirreno CentroMeridionale. Biologia Marina Mediterranea, 2: 239-244.

TAYLOR, C. C., 1962. Growth equation with metabolic parameters. Journal du Conseil International pour l'Exploration de la Mer, 27: 270-286.

Yahiaoui, M., A. NouAR \& A. Messili, 1986. Evaluation des stocks de deux espèces de crevettes profondes de la famille des pénéidés: Aristeus antennatus et Parapenaeus longirostris. FAO Fishery Report, 347: 221-231.

First received 28 February 2011.

Final version accepted 25 May 2011. 